\title{
Author Correction: Structures of the stator complex that drives rotation of the bacterial flagellum
}

Justin C. Deme (i), Steven Johnson (1D, Owen Vickery (1), Amy Aron, Holly Monkhouse, Thomas Griffiths (1), Rory Hennell James, Ben C. Berks, James W. Coulton, Phillip J. Stansfeld and Susan M. Lea (D)

Correction to: Nature Microbiology https://doi.org/10.1038/s41564-020-0788-8, published online 14 September 2020.

In the version of this Article originally published, the surname of the author Amy Aron was mistakenly written as 'Muellbauer'. This error has been corrected.

Published online: 9 November 2020

https://oi.org/10.1038/s41564-020-00825-4

( ) The Author(s), under exclusive licence to Springer Nature Limited 2020 